\title{
Preventing the natural hazards and protection against floods in a deltaic area
}

\author{
Cătalin Popescu ${ }^{1, *}$ Constantin Alin Stanca ${ }^{1}$, Petruta Isofache $^{1}$, and Altan Abdulamit ${ }^{1}$ \\ ${ }^{1}$ Technical University of Civil Engineering of Bucharest, Hydraulic Engineering Department, Romania
}

\begin{abstract}
The project of preventing the natural hazards and protection against floods of city Babadag has been designed to protect river banks of Tabana brook and its tributaries inside the area of city Babadag, against floods and silting phenomenon. The project contributes to the protection of infrastructure and social economic objectives, being in danger to deteriorate or even to be destroyed if this project will not be implemented. Aside protection of infrastructure and economic objectives, this study has another extremely important purpose for the community protection and improvement of the environmental quality and living standards from the area.
\end{abstract}

\section{Introduction}

The designed works are located within the urban area and outside the urban area of Babadag locality, in the main channel of Tabana Brook as well as on its tributaries. From the administrative-territorial division point of view, the works are located in Tulcea County. Babadag locality is located at $35 \mathrm{~km}$ South of Tulcea Town and $90 \mathrm{~km}$ North of Constanta Town.

The access to this region is possible through the DN 22 road Constanta-Tulcea and streets from Babadag locality.

\section{Climate and hydrology conditions}

Babadag city area frames within the temperate continental climate of the country, but shows a series of particularities due to local factors, such as: position close to Danube's spillway and Black Sea coast, relief morphology (couloirs and marginal depressions in West, North and East), mountains and hills altitudes from North-West and South. In the Babadag area the average annual temperature is of $10.7^{\circ} \mathrm{C}$. The maximal value occurs in August $\left(26.5^{\circ} \mathrm{C}\right)$ within Babadag area.

The predominant winds blow with a higher frequency from NE (18.3\%), followed by the ones from NV (17.1\%), E (15.2\%) and $\mathrm{N}(13.1 \%)$, with average annual speeds between 0.8 and $5.3 \mathrm{~m} / \mathrm{s}$.

The torrential character of rainfalls has a negative influence by the floods it generates followed by pronounced torrential erosions, especially in loess deposits.

The hydrological data required to draw up this documentation, consisting in maximum flow values with various probabilities of overflow in the main modelling sections on Tabana River and its tributaries from Babadag city (Batacali, Moş Lange, Havraliuc, Bendea, Kios-Kula, and other 4 valleys which are not in the hydrographic cadastral survey) were provided by I.N.H.G.A. (National Institute of Hydrology and Water Management) during 2015.

The configuration of the hydrographical network and model sections disposal is presented in Fig. 1.

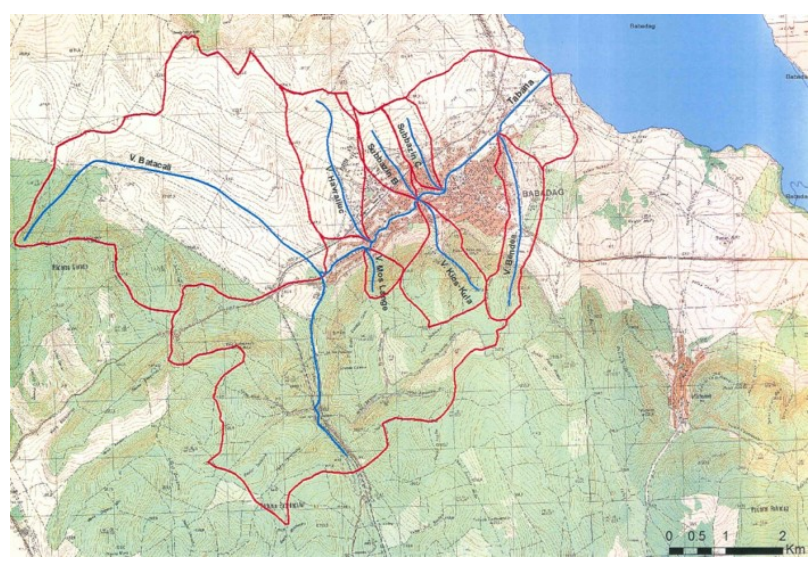

Fig. 1. Sub-drainage basins delimitation - Tabana river.

The values of peak flow refer to the overflow probability of $0.5 \%, 1 \%, 2 \%$ and $5 \%$.

For estimation of natural regime pea, a detailed analysis of the existing documentations was conducted, in terms of maximal drainage characteristics within the hydrographical space between Tulcea Hills in North and Babadag Plane in South.

The estimation methodology of peak flow has been accomplished using the hydrographic basin characteristics for each section.

\footnotetext{
* Corresponding author: catalin.popescu@utcb.ro
} 
Digital Terrain Model has been performed using Global Mapper software and HEC-RAS software has been used to perform flow calculations for this project.

Validation of resulted data has been accomplished by the Romanian authority (I.N.H.G.A) mentioned above.

Peak flow values with overflow probabilities of $0,5 \%$, $1 \%, 2 \%$ and $5 \%$ determined according to the specified authority, are presented in table 1 .

Table 1. Computed peak flow for different overflow probabilities.

\begin{tabular}{|c|c|c|c|c|c|c|c|c|}
\hline \multirow{2}{*}{$\begin{array}{l}\text { No. } \\
\text { Item }\end{array}$} & \multirow{2}{*}{$\begin{array}{l}\text { River } \\
\text { V. Mos } \\
\text { Lange }\end{array}$} & \multirow{2}{*}{$\begin{array}{c}\text { Section } \\
\\
\begin{array}{c}\text { Upstream cfl. } \\
\text { Tabana }\end{array}\end{array}$} & \multirow{2}{*}{$\begin{array}{c}\mathrm{F} \\
{[\mathrm{km} 2]}\end{array}$} & \multirow{2}{*}{ 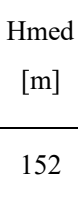 } & \multicolumn{4}{|c|}{$\begin{array}{c}\text { Maximum discharge } \\
{[\mathrm{m} 3 / \mathrm{s}]} \\
\text { Q0.5\% Q1\% Q2\% Q5\% }\end{array}$} \\
\hline & & & & & 7 & 5.6 & 4 & 3 \\
\hline 2 & $\begin{array}{c}\text { Sub- } \\
\text { drainage } \\
\text { basin C }\end{array}$ & $\begin{array}{l}\text { Upstream cfl, } \\
\text { Tabana }\end{array}$ & 0.78 & 74 & 12 & 10 & 8 & 5 \\
\hline 3 & $\begin{array}{c}\text { Sub- } \\
\text { drainage } \\
\text { basin B }\end{array}$ & $\begin{array}{c}\text { Upstream cfl. } \\
\text { Tabana }\end{array}$ & 1.03 & 85 & 16 & 13 & 10 & 7 \\
\hline 4 & Bendea & $\begin{array}{c}\text { Upstream cfl. } \\
\text { Tabana }\end{array}$ & 1.78 & 116 & 26 & 21 & 17 & 11 \\
\hline 5 & Kios-Kula & $\begin{array}{l}\text { Upstream cfl. } \\
\text { Tabana }\end{array}$ & 1.9 & 181 & 27 & 22 & 17 & 12 \\
\hline 6 & $\begin{array}{c}\text { V. } \\
\text { Havraliuc }\end{array}$ & $\begin{array}{l}\text { Upstream cfl. } \\
\text { Tabana }\end{array}$ & 2.9 & 97 & 38 & 31 & 24 & 17 \\
\hline 7 & Tabana & $\begin{array}{l}\text { Upstream cfl } \\
\text { V. Batacali }\end{array}$ & 13.65 & 170 & 102 & 84 & 66 & 46 \\
\hline 8 & Batacali & $\begin{array}{c}\text { Upstream cfl. } \\
\text { Tabana }\end{array}$ & 15.2 & 132 & 106 & 87 & 68 & 47 \\
\hline 9 & Tabana & $\begin{array}{l}\text { Upstream cfl. } \\
\text { V. Mos Lange }\end{array}$ & 29.3 & 149 & 141 & 116 & 91 & 63 \\
\hline 10 & Tabana & $\begin{array}{l}\text { Upstream cfl. } \\
\text { V. Havraliuc }\end{array}$ & 29.73 & 149 & 142 & 117 & 92 & 64 \\
\hline 11 & Tabana & Bridge 4 & 32.7 & 143 & 145 & 119 & 94 & 65 \\
\hline 12 & Tabana & $\begin{array}{c}\text { Upstream cfl. } \\
\text { Subbazin B }\end{array}$ & 33.7 & 141 & 147 & 121 & 95 & 66 \\
\hline 13 & Tabana & $\begin{array}{l}\text { Upstream cfl. } \\
\text { Kios-Kular }\end{array}$ & 34.8 & 140 & 150 & 123 & 97 & 67 \\
\hline 14 & Tabana & $\begin{array}{l}\text { Upstream cfl. } \\
\text { Subbazin C }\end{array}$ & 36.9 & 141 & 155 & 127 & 100 & 69 \\
\hline 15 & Tabana & $\begin{array}{l}\text { Upstream cfl. } \\
\text { Bendea }\end{array}$ & 40.5 & 135 & 163 & 134 & 105 & 73 \\
\hline 16 & Tabana & $\begin{array}{l}\text { Upstream } \\
\text { Lac Babadag }\end{array}$ & 45.5 & 127 & 173 & 142 & 112 & 77 \\
\hline
\end{tabular}

In the study process, other small hydrographic subdrainage basins with torrential potential have been identified for which were determined peak flow values with various overflow probabilities.

Positioning the sections and torrential hydrographic sub-drainage basins for which were determined supplementary values of the maximum drainage are presented in Fig. 2.

Peak flow values with various probabilities of overflow for the torrential valleys on which are proposed works specific to torrents adjustment are presented in table 2:

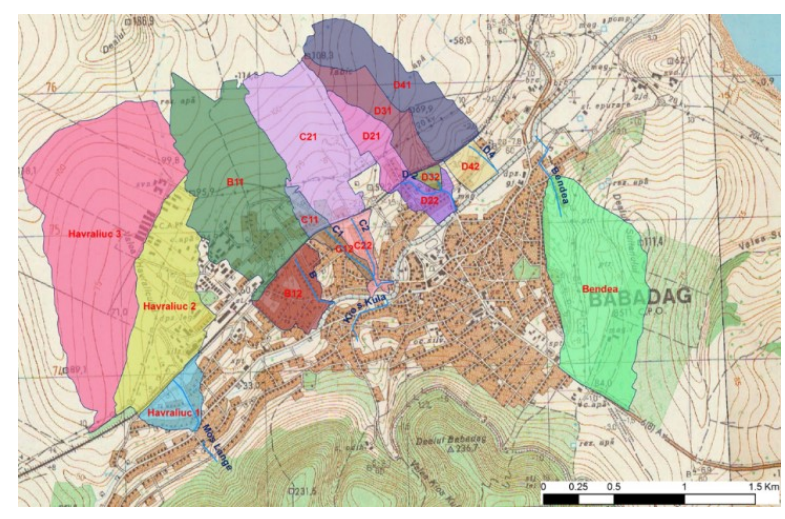

Fig. 2. Torrential sub-basins delimitation - Tabana river Babadag city.

Table 2. Computed peak flow for different overflow probabilities.

\begin{tabular}{lllllll}
\hline \multirow{2}{*}{ River } & \multirow{2}{*}{ Section } & $\mathrm{F}\left[\mathrm{km}^{2}\right]$ & \multicolumn{4}{c}{$\mathrm{Qmax}\left[\mathrm{m}^{3} / \mathrm{s}\right]$} \\
& & & $\mathrm{Q} 05 \%$ & $\mathrm{Q} 1 \%$ & $\mathrm{Q} 2 \%$ & $\mathrm{Q} \%$ \\
\hline $\mathrm{D} 4$ & $\mathrm{D} 41$ & 0.396 & 6.71 & 5.5 & 4.29 & 2.97 \\
$\mathrm{D} 3$ & $\mathrm{D} 31$ & 0.207 & 4.88 & 4 & 3.12 & 2.16 \\
D2 & D21 & 0.142 & 4.03 & 3.3 & 2.57 & 1.78 \\
C2 & C21 & 0.550 & 9.76 & 8 & 6.24 & 4.32 \\
C1 & C11 & 0.048 & 2.38 & 1.95 & 1.52 & 1.05 \\
B & B11 & 0.868 & 12.81 & 10.5 & 8.19 & 5.67 \\
\hline
\end{tabular}

Having all the necessary data for the final design for the affected areas, in the following chapter will be presented technical solution designed to protect against floods and natural hazard prevention within the studied area.

\section{About the project}

The necessity and opportunity of the studied project are generated by the necessity of preventing and placing under safety conditions against floods social-economic objectives, households and households annexes, communication infrastructures, water supply resources, as well as of sewerage systems and not least the loss of human life.

Coastal streams with torrential character producing strong erosion and transport of solid material from slopes in Tabana Brook are formed during heavy rains in spring, as well as the snow melting. The floods causes which result in damages and have affected the social-economic objectives in Babadag locality are due to unpredictable heavy rains, lack of the soil erosion control works and non-achievement of an optimum running section of the Tabana Brook. The necessity and opportunity of soil erosion control works are determined by their utility in diminishing the area and the intensity of degradation processes of the soils from agricultural lands, of damages caused by floods and decreasing of the water running on slopes and valleys of Babadag Town. 
Due to a lack of a plan regarding the soil erosion control works, the degradation processes are increasing as time goes on.

In these circumstances, we consider that on these lands (slopes and ravines) it is necessary to urgently interfere to combat the negative effects of degradation processes with soil erosion control works throughout the whole catchment area of the Tabana Brook.

Works to combat soil erosion are designed to stop the alluvial material on slopes that would clog the riverbed Tabana, to reduce flow and volume of floods. The alluvial material that is coming off during floods ends up in Babadag Lake, a lake which in time will clog if no measure for soil erosion is implemented. Babadag Lake is part of the protected area NATURA 2000.

By using soil erosion control works in conjunction with regularization of the Tabana Brook in Babadag locality, will reduce the damage caused by floods and the economic and social objectives as well as the city infrastructure will be better protected.

\subsection{Possible solutions}

To prevent and control floods from Tabana brook and to reduce soil erosion from slopes from Tabana brook riverbanks, a number of works presented in this project are the following:

- Attenuation of the flood wave in upstream of Tabana river (by carrying out of the Temporary Storage Reservoir on Batacali Valley);

- Calibration of Tabana brook in city Babadag;

- Measurement plans regarding soil erosion;

- Reconstruction of current bridges by increasing the transport capacity of the riverbed.

Modelling the water flow on Tabana River from Babadag urban area was achieved on a sector of approx. $5.5 \mathrm{~km}$, delimited upstream by the confluence with Batacali valley and downstream by the flow into Babadag Lake. In the hydraulic calculus, the modelled sector was expanded also on Batacali valley, from the confluence with Tabana river to upstream, the undercrossing of the railway, on a length of approx. 0.8 $\mathrm{km}$.

There were used 39 cross section for the entire modelled sector of approx. $6.3 \mathrm{~km}$ length, composed of the Batacali River channel, upstream of the confluence with Tabana River, and Tabana River until the flow into Babadag lake. Also, in the hydraulic modelling were comprised the sections of main bridges which cross Tabana channel. Among the bridges included in the modelling, 5 of them are located on DN 22.

The placement of calculus profiles and the main bridges crossing Tabana river on the modelled sector is shown in Fig. 3.

After analysing, the possibilities of placing the temporary reservoir upstream of Babadag urban area, was identified as feasible the site on Batacali valley.

Batacali valley is the main tributary of Tabana river. It is a left-side tributary which confluences Tabana right upstream of Babadag urban area, after undercrossing the railroad Constanta-Tulcea, and has a basin surface comparable with Tabana's in the confluence section.

- The surface of Tabana hydrographic drainage basin upstream of confluence with Batacali is $13.65 \mathrm{sq} . \mathrm{km}$

- The surface of Batacali hydrographic drainage basin upstream of confluence with Tabana is 15.20 sq. $\mathrm{km}$

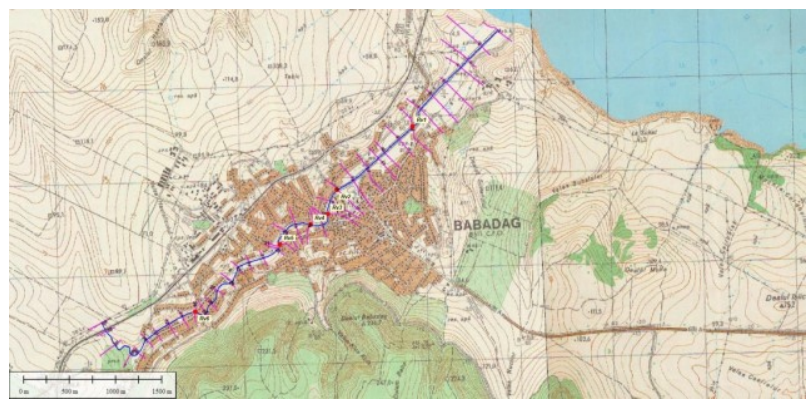

Fig. 3. Cross-section and main bridges location - Tabana River - Babadag City.

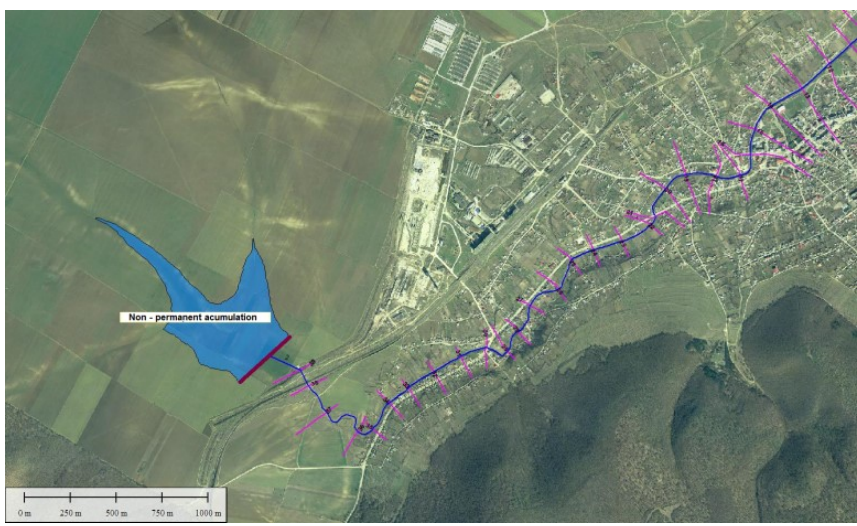

Fig. 4. Batacali temporary reservoir location.

Batacali valley has an important share in the composition of flood waves in Babadag urban area, the surface of the hydrographic drainage basin is approx. $33.4 \%$ of the total surface of Tabana hydrographic drainage basin.

For the peak flow with overflow probability of $0.5 \%$, the maximal flow is dropping from $106 \mathrm{~m}^{3} / \mathrm{s}$ to approx. $13 \mathrm{~m}^{3} / \mathrm{s}$, a volume of approx. $0.59 \mathrm{mil} . \mathrm{m}^{3}$ is stored when level of water storage reaches elevation of $61.17 \mathrm{mdMN}$.

Maximum discharge time is approx. 22 hours.

So, in downstream section confluence of Tabana river with Batacali valley, for the option of executing the temporary Batacali storage, by composing the flood waves components of the two rivers in hypothesis of an uniformly spilled layer, peak flow value with overflow probability $0.5 \%$ is dropping from approx. $141 \mathrm{~m}^{3} / \mathrm{s}$ to approx. $75 \mathrm{~m}^{3} / \mathrm{s}$.

The temporary storage Batacali has a significant influence over the hydrological regime of Tabana river, achieving a mitigation of approx. 47\% upstream of Babadag urban area. 
At discharge in Babadag lake, value of peak flow corresponding to the overflow probability of $0.5 \%$ is dropping from approx. $173 \mathrm{~m}^{3} / \mathrm{s}$ to approx. $114 \mathrm{~m}^{3} / \mathrm{s}$ reaching a mitigation of $34 \%$.
The analysed surface for the soil erosion control works proposed in hydrographical basin Tabana is about 1,830 ha.

The current use of land where construction works

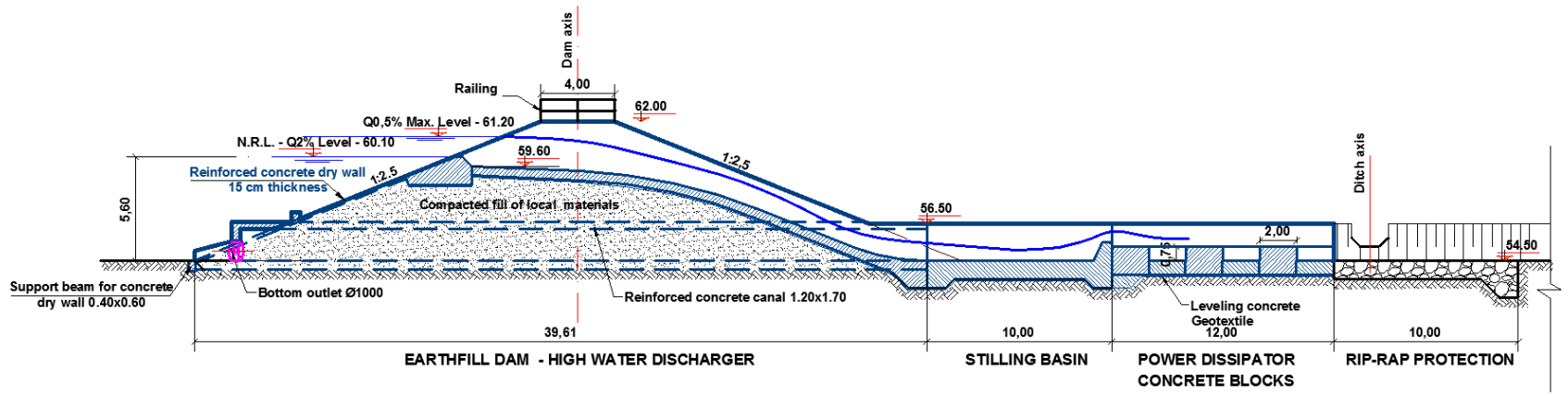

Fig. 5. Non-permanent accumulation - Cross section.

Downstream of water storage, transport capacity of Tabana brook has been increased with a new design of riverbed and river banks.

Natural riverbed is replaced with a $20 \mathrm{~cm}$ thick reinforced concrete pitch for upstream zone and for downstream zone natural riverbed is completed with riprap rock.

This works has been divided in three different shapes, one for each zone (upstream, central and downstream), as can be seen in Fig. 6 . needs to be used for construction is: agriculture land, pastures, grassland, forest and non-agricultural land and here are proposed soil erosion control works on the valleys and ravines route located on the riverbank slopes of Tabana brook.

These works intend to intercept, collect and convey the pluvial waters in excess in a controlled manner (without affecting the urban area) towards the natural emissary from the area (Tabana brook) or to stop and storage part of the conveyed sediments on these valleys (the transverse hydraulic works proposed on ravines are of stone masonry with cement mortar).

The proposed general development scheme includes

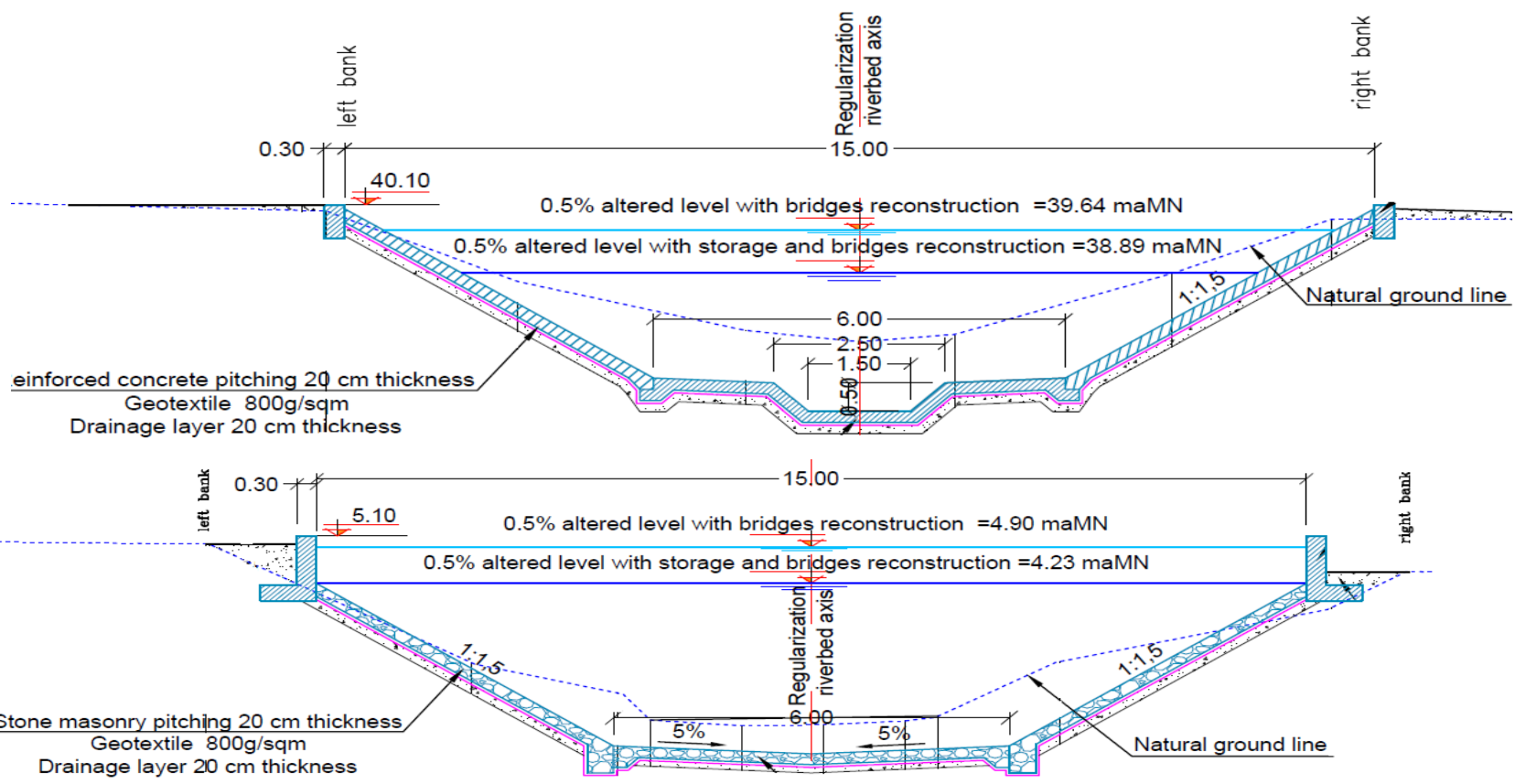

Fig. 6. Cross-section on Tabana brook.

a) Upstream cross-section; b) Downstream cross-section

The surrounding within the urban area of city Babadag, where soil erosion control construction works should be carried out for flood mitigation and dropping the contribution of sediments conveyed towards Tabana brook. hydro-ameliorative works for controlling the soil erosion, grouped by types of erosion which are occurring in the area, thus:

- transverse hydraulic works on valleys and ravines:

- $\quad$ dams made out of stone masonry, 10 pcs;

- $\quad$ sills made out of stone masonry, 6 pcs;

- $\quad$ crossings made out of stone masonry, 9 pcs;

- forest protection plantation on ravines (foresting), 4.66 ha; 
- $\quad$ discharge channel, 1,030 Km length;

- $\quad$ stone masonry, 23 pcs,

- $\quad$ and 4 pes culverts.

Studied and proposed works are environmentally friendly, an easy method of carrying out the works in heavy access conditions on the ravines.

Also, materials consumption have been reduced, by using local materials and mean qualification (local) labour.

On the territory of Babadag Town are carried out two-way communication paths national road and railway, Medgidia-Tulcea railway and national road DN 22 Constanta-Tulcea, as well as one of local road county road DJ 223 A, Ciucurova - Babadag - Enisala.

A number of 5 bridges across Tabana brook are placed close to city Babadag.

The current situation is difficult to resolve from the transiting capacity of the flood flows point of view, especially in the location sections of the crossing works of Tabana Brook.

It should be noted that the current bridges from national road DN 22, have reduced openings from 12.00 to $5.00 \mathrm{~m}$ length and free heights under the bridge of 3.00 $\mathrm{m}$ to $1.50 \mathrm{~m}$, which leads to the conclusion that flood transition cannot be realised.

The technical proposed solution for carrying out the bridges is to achieve new bridges with a single opening of $18.00 \mathrm{~m}$ length of the superstructure positioned on vertical at elevations by means of which the free-board of $1.00 \mathrm{~m}$ in regard to the designed discharge for national roads.

In Fig. 7 is a typical cross section proposed to be used for all bridges

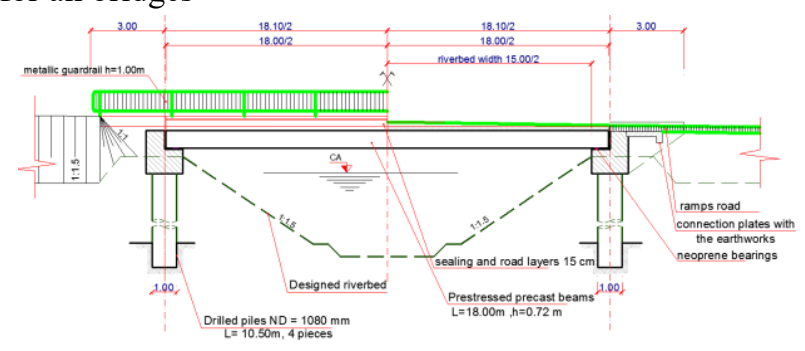

Fig. 7. Proposed bridge - cross-section.

\subsection{The impact of the studied works over the environment}

The impact of projected works on the environment, make this the subject of a complex study, study referring to the whole complex of works including those hydrotechnical works.

Hydrotechnical works within the present paper does not produce and does not issue pollutants in the environment.

Flood protection works and soil erosion control works from Babadag locality shall be developed near some natural protected areas: ROSPA0091 Babadag Forest, ROSPA0031 Danube Delta and Razim Sinoe
Complex, ROSCI0201 Northern Dobrogea Plane Dobrogean and ROSCI0065 Danube Delta.

Impact of hydrotechnical works over the environmental factors differs in regard to the execution and operation periods.

The areas possibly affected by landslides will be stabilized by means of the soil erosion control works.

Also, these areas will have a long-term positive landscape impact.

The proposed hydrotechnical works will maintain the existing natural frame and they are framing in the local ecological system. The proposed hydrotechnical works are framing in the previsions of The Protection Plan against floods in Tulcea County.

During the operation period, practically the impact of the hydrotechnical works over the biocoenosis is insignificant, their aim is to prevent floods and maintaining of the current characteristics of the water streaming.

The only time in which an impact over the biodiversity components will exist is the execution period, but this is limited in time and space and the effects will disappear in a relatively short time after works completion.

Generally, the protection works against floods will be carried out along the Tabana riverbed and its tributaries but also in the area of Batacali Valley where a temporary storage reservoir will be developed.

Designed works have the goal to stop, prevent and control floods and erosion by placing in safe conditions the households from the area and avoid the occurrence of major flood events.

Considering these, the impact of works over social factor is positive and favours the general development of the area and increases the trust amongst the population and economic agents from the area in terms of protection of their possessions.

Foreseen works will be gradually integrated into the natural frame, by systemizing adaptions of objectives from sites perimeters, and their completion and maintenance shall be followed up by "Operation Regulations".

By adopted technical solutions are achieved works, which classify in the natural assembly according to urban development plans of the locality.

This project frames within objectives of Plan for Protection against Floods in Tulcea County (2012-2017), approved by Tulcea County Council.

This plan imposes a reconsideration of socioeconomic objectives protection within county territory based on some studies which include morphological changes in Danube Delta and elaboration of a united program for water management and protection, by identifying the financial sources for their application.

\section{Conclusions}

The purpose of the investment objective, above mentioned, is to prevent and to place under safety 
conditions against floods of the social-economic objectives, households and households annexes, communication means, water supply systems as well as sewerage systems and not least the loss of human lives.

The beneficiaries of the hydraulic engineering structures proposed within the project are the Babadag city residents.

The project is included in "National Strategy For Prevention, Protection And Mitigation Of Flood Effects Within The Hydrographical Basin Dobrogea - Litoral".

Technical solutions within the documentation of the project is based on hydraulic calculations, results and proposals made in the project "Flood hazard maps of Littoral Hydrographic Basin and Plan for Prevention, Protection and Mitigation of Floods".

Through the technologies established and described in this project, the natural environment is not disturbed and pollutants factors which could affect the environment are not occurred.

Technical designed solutions and hydraulic engineering structures for developing and rearrangement of the water courses from this project have been established being environmentally friendly and reaching the environmental objectives in the field of water management.

As a conclusion, protection against floods in the area of Babadag city will have a positive effect over the environment by:

- Avoiding damages generated by floods over the households, social cultural objectives, agricultural lands, and national road DN 22;

- $\quad$ Providing of a higher stability of the population within the area;

- $\quad$ Providing of a higher life level for the population in the protected area.

On this occasion, we would like to express our sincere and deep gratitude to AQUAPROIECT S.A. - Romania, for the completion of the project and the support data provided for the article that could not have been accomplished without the hard work of a great team of dedicated engineers. These acknowledgments must be credited to S.C. Aquaproiect S.A. Romania and all the team that participated to the supporting documents of this article.

\section{References}

[1] Aquaproiect Company. TECHNICAL ASSISTANCE FOR PREPARING THE PRIORITY AXIS 5 PROJECTS - Implementation of the adequate structure for preventing the natural hazards in the most exposed areas - Major intervention domain 1 - Protection against floods „PROTECTION AGAINST FLOODS OF BABADAG LOCALITY IN TULCEA COUNTY"; 2015.

[2] Plan for Protection against Floods in Tulcea County (2012-2017), approved by Tulcea County Council.

[3] Technical-economic documentation, Phase: Technical Design, Specifications and Execution Detail and Field Studies; 2005.
[4] Technical expertise for bridges on DN 22.

[5] Provisions of Development Plan of Dobrogea Litoral Hydrographic discharge basin elaborated by I.N.H.G.A.

[6] D. Stematiu, D. Paunescu, Slope stability of large reservoir banks. Slope instability in the Sacele dam hightening conditions. Proc. of VIIth Benchmark Workshop on Numerical Analysis of Dams (2003). 